Special Issue of the 8th International Advances in Applied Physics and Materials Science Congress (APMAS 2018)

\title{
The Effect of Ageing Temperature in T6 Heat Treatment on Mechanical Properties of AA7075
}

\author{
I. SimseK ${ }^{a, *}$, D. SimseK ${ }^{b}$, T. TUnCAY ${ }^{c}$ And D. OzYUREK ${ }^{c}$ \\ ${ }^{a}$ Karabuk University, TOBB Tech. Sci. Voc. Sch., Program of Mach. and Metal Tech., Karabuk, Turkey \\ ${ }^{b}$ Bitlis Eren University, Tech. Sci. Voc. Sch., Program of Automotive Tech., Bitlis, Turkey \\ ${ }^{c}$ Karabuk University, Technology Faculty, Department of Manufacturing Eng., Karabuk, Turkey \\ In this study, the effect of ageing temperatures in T6 heat treatment on the microstructural changing and \\ mechanical properties of AA7075 were investigated. The samples were quenched after solution treatment at $485^{\circ} \mathrm{C}$ \\ for $2 \mathrm{~h}$. The natural ageing was applied for $1 \mathrm{~h}$, and then artificial ageing was carried out at five different \\ temperatures $\left(100-140^{\circ} \mathrm{C}\right)$ for $24 \mathrm{~h}$. Hardness measurements, microstructure, X-ray diffraction examinations, and \\ tensile tests of aged samples were carried out. As a result of the study, the hardness values and ultimate tensile \\ stress values were increased by increasing ageing temperatures up to $120^{\circ} \mathrm{C}$. Then it was decreased by increasing \\ ageing temperature. Ultimate tensile stress values were compatible with hardness values and maximum ultimate \\ tensile stress values were obtained in aged samples at $120^{\circ} \mathrm{C}$.
}

DOI: 10.12693/APhysPolA.135.732

PACS/topics: AA7075, ageing temperature, microstructure, tensile strength.

\section{Introduction}

7xxx series alloys are the most commonly used aluminum alloys in different fields of industry. They are widely used in defence, automotive, and particularly aviation industries due to advantages such as high strength/weight ratio and natural ageing properties [1] Also, high solid solubility of zinc $(\mathrm{Zn})$ and magnesium $(\mathrm{Mg})$ in the alloy provides improved precipitation hardening and therefore improves strength [2-4]. It is possible to improve the strength of $7 \mathrm{xxx}$ series alloys using various heat treatment methods. The highest hardness value is obtained by the $\mathrm{T} 6$ heat treatment method. T6 heat treatment involves both the solution heat treatment and the artificial ageing treatment applied to the alloy following the solution heat treatment. These heat treatments are the most important factors improving the mechanical properties of the alloy $[5,6]$. Ageing treatment can be applied both naturally and artificially. Second phase precipitates formed in the structure by ageing treatment improve the strength of the alloy [7]. This study aims to investigate the effect of the ageing temperature on microstructure, hardness, and tensile strength of the AA7075 alloy aged using five different ageing temperatures.

\section{Experimental procedure}

Table I shows the chemical composition of the alloy used in the experimental studies. The specimens prepared for tensile tests were exposed to T6 heat treatment. The specimens were rapidly cooled after solution

*corresponding author; e-mail: ijlalispir@karabuk.edu.tr treatment at $485^{\circ} \mathrm{C}$ for $2 \mathrm{~h}$. After natural ageing at room temperature for $24 \mathrm{~h}$, the alloys were artificially aged at five different temperatures $\left(100-140^{\circ} \mathrm{C}\right)$ for $24 \mathrm{~h}$. The hardness measurement of the alloys was performed using Affri System hardness measurement device, and the average of five measurements was taken. The alloys prepared by standard metallographic procedures were seared using Keller's solution for 10-15 s. JEOL JSM-6060 scanning electron microscope (SEM) was used for microstructure examinations and imaging fractured surfaces after the tensile testing. Rigaku D-Max Rint-2200 Series brand device was used for XRD analysis to determine phases formed in the microstructure.

TABLE I

The chemical composition of the AA7075 alloy used in the experimental studies

\begin{tabular}{c|c|c|c|c|c|c}
\hline \hline Element & $\mathrm{Zn}$ & $\mathrm{Mg}$ & $\mathrm{Cu}$ & $\mathrm{Fe}$ & $\mathrm{Cr}$ & $\mathrm{Si}$ \\
\hline wt\% & 5.9 & 2.734 & 1.561 & 0.196 & 0.2 & 0.0117 \\
\hline \hline Element & $\mathrm{Mn}$ & $\mathrm{Ti}$ & $\mathrm{V}$ & $\mathrm{Zr}$ & $\mathrm{B}$ & $\mathrm{Al}$ \\
\hline wt\% & 0.0687 & 0.0343 & 0.0066 & 0.0091 & 0.0025 & bal.
\end{tabular}

\section{Results and discussion}

Figure 1 shows the microstructure SEM images of the alloys which were solution treated at $485^{\circ} \mathrm{C}$ and then aged at different temperatures for $24 \mathrm{~h}$.

Microstructure SEM images of the AA7075 alloy aged at $100{ }^{\circ} \mathrm{C}$ (Fig. 1a) and $120^{\circ} \mathrm{C}$ (Fig. 1b) given in Fig. 1 shows that second phase precipitates are formed in the structure. Microvoids (Fig. 1b) were also observed depending on the ageing temperature applied to the alloy. Characteristic structures obtained after T6 heat treatment included GP zones, metastable $\mathrm{MgZn}_{2}$ precipitates, 

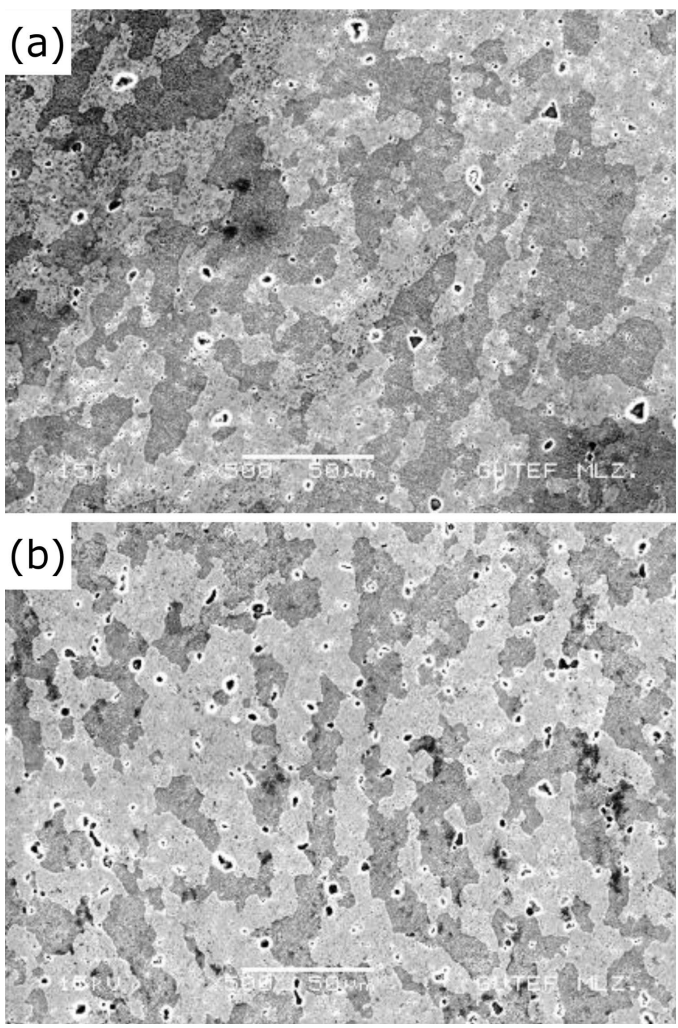

Fig. 1. The microstructure SEM images of the AA7075 alloy aged at $100^{\circ} \mathrm{C}(\mathrm{a})$ and $120^{\circ} \mathrm{C}(\mathrm{b})$ for $24 \mathrm{~h}$.

and stable $\mathrm{MgZn}_{2}$ precipitates [8]. It was reported in a previous study that precipitates formed in the structure after ageing treatment both at grain centers and grain boundaries [9]. Figure 2 shows the X-ray diffraction (XRD) results of the AA7075 alloy aged at $120^{\circ} \mathrm{C}$, hardness and tensile strength variation in the alloys T6 heat treated at different temperatures.

The XRD results given in Fig. 2a shows that $\mathrm{MgZn}_{2}$ formed in the structure of the alloy. Second phase precipitates are the most important factors improving the strength of the alloy. In some previous studies, it was reported that different phases such as $\mathrm{Al}_{7} \mathrm{Cu}_{2} \mathrm{Fe}$ and $\mathrm{Al}_{2} \mathrm{CuMg}$ formed in the structure in addition to $\mathrm{MgZn}_{2}$ precipitates $[8,10]$. In another study, it was noted that it is not possible to say that these precipitate phases have formed during the ageing treatment [11]. Figure $2 \mathrm{~b}$ shows that the hardness values of the alloys, aged at different ageing temperatures for $24 \mathrm{~h}$, increase by the increasing ageing temperature. The minimum hardness value $(212 \mathrm{HV}$ ) was obtained for the alloy aged at $120^{\circ} \mathrm{C}$. This may be explained with the Orowan mechanism. The increased temperature in ageing treatment results in increased second phase precipitates, which hinder dislocations, thereby producing the maximum hardness value. Kalyon and Özyürek [12] noted that ageing heat treatment improved the strength of the alloy, which was a result of hindered dislocation movements by second phase precipitates. A decrease was observed in the hardness value of the alloy when the ageing temperature was increased further. An ageing temperature of $130^{\circ} \mathrm{C}$ and $140^{\circ} \mathrm{C}$ produced a hardness value of $191 \mathrm{HV}$ and $184 \mathrm{HV}$, respectively. This indicates that the alloy entered the over-ageing period with the increase in ageing temperature. The further increase in the temperature leads to coarse second phase precipitates and decreased hardness value. The chart obtained as a result of tensile tests performed for the samples aged at different temperatures for $24 \mathrm{~h}$ (Fig. 2b) shows that the tensile strength increased with the increasing temperature. The maximum tensile strength value of $620 \mathrm{MPa}$ was obtained for the alloy aged at $120^{\circ} \mathrm{C}$. This is due to precipitation of second phases dissolved in the supersaturated solid solution as metastable $\eta^{\prime}\left(\mathrm{MgZn}_{2}\right)$ phase with increasing temperature. A decrease was observed in the tensile strength of the alloy when the ageing temperature was increased further $\left(130^{\circ} \mathrm{C}\right.$ and $\left.140^{\circ} \mathrm{C}\right)$. The tensile strength value obtained for the alloy aged at $140^{\circ} \mathrm{C}$ was $584 \mathrm{MPa}$ due to increased ageing temperature. This decrease in the tensile strength is a result of metastable $\eta^{\prime}\left(\mathrm{MgZn}_{2}\right)$ phase's over-ageing due to increased temperature. Mukhopadhyay et al. [13] reported that stable $\eta$ phase $\left(\mathrm{MgZn}_{2}\right)$ formed in the structure led to a decrease in the tensile strength and the hardness of the alloy. Figure 3 shows the fractured surface SEM images of the AA7075 alloys aged at $100^{\circ} \mathrm{C}$ and $120^{\circ} \mathrm{C}$ after the tensile testing.
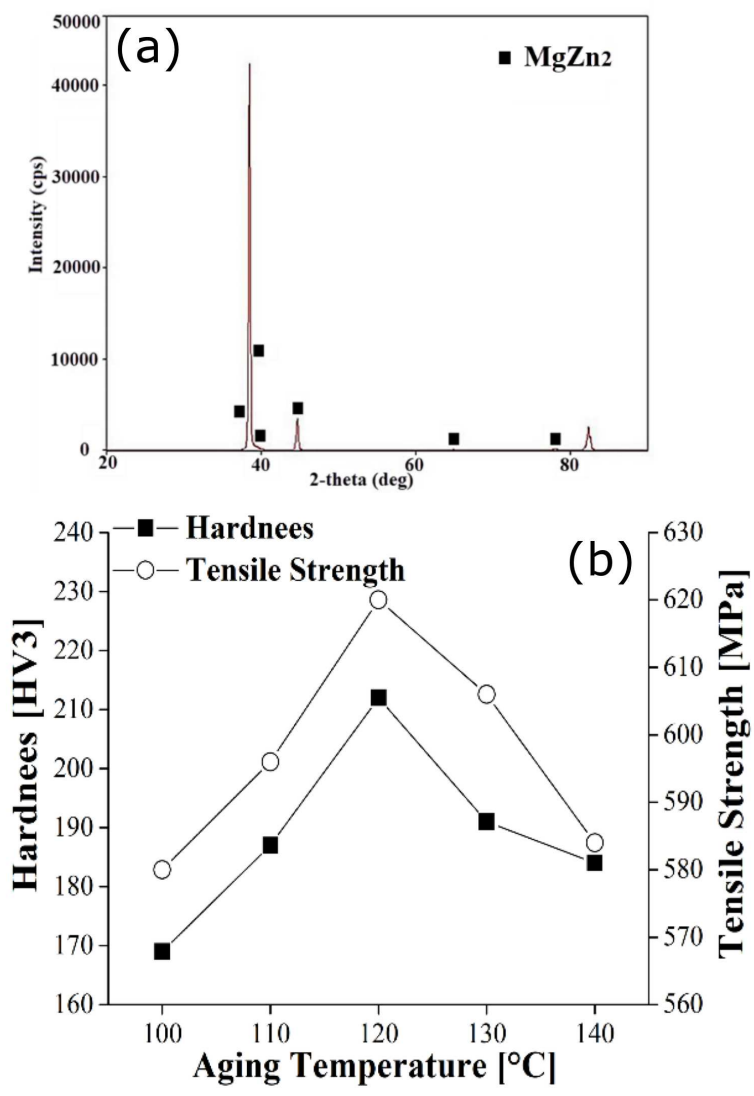

Fig. 2. The XRD results of the AA7075 alloy aged at $120^{\circ} \mathrm{C}(\mathrm{a})$, and hardness and tensile strength variation in the alloys T6 heat treated at different temperatures (b). 


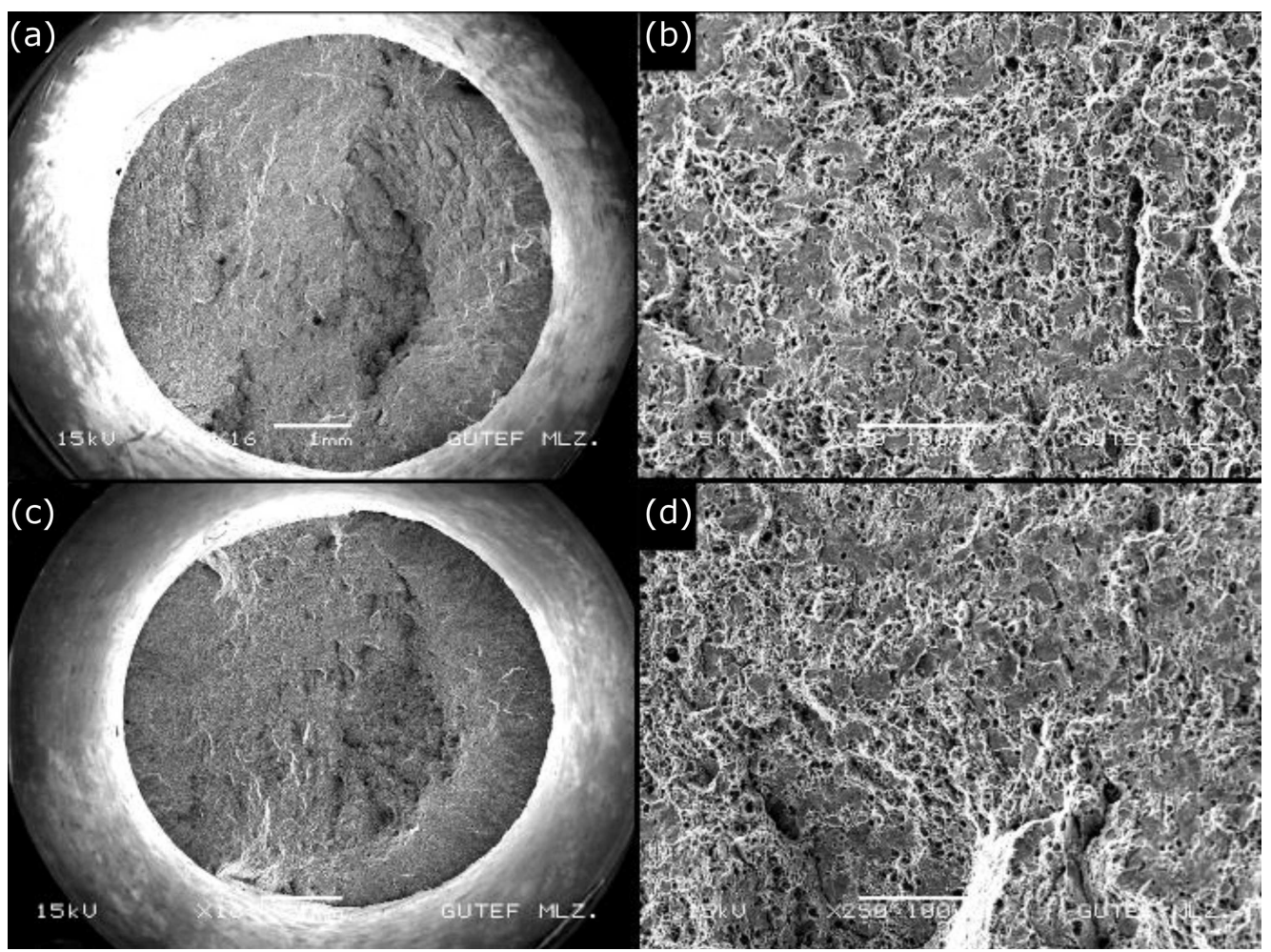

Fig. 3. The fractured surface SEM images of the AA7075 alloys, aged at $100^{\circ} \mathrm{C} 16 \times(\mathrm{a}), 100^{\circ} \mathrm{C} 250 \times(\mathrm{b})$ and $120^{\circ} \mathrm{C}$ $16 \times(\mathrm{c}), 120^{\circ} \mathrm{C} 250 \times(\mathrm{d})$ after the tensile testing.

The fractured surface SEM images given in Fig. 3a and $\mathrm{b}$ shows that although the planar fracture mechanism is observed, the ductile fracture mechanism was dominant on the fractured surface (Fig. 3b and d). It was observed that micro-voids in the structure of the alloy enlarged due to increased ageing temperature. Also, deep pits formed on the fractured surfaces. The formation of $\mathrm{MgZn}_{2}$ precipitates in the structure of the alloy due to increased ageing temperature is an important parameter improving the strength of the alloy. As can be understood from the fractured surface images, this is also the reason behind planar fracture.

\section{Conclusion}

The following results were obtained in this study investigating the mechanical properties of the AA7075 alloy aged at different temperatures.

- It was found that second phase $\left(\mathrm{MgZn}_{2}\right)$ precipitates formed in the alloy's structure because of ageing heat treatment.

- The maximum hardness value was obtained for the alloy aged at $120^{\circ} \mathrm{C}$. Further increase in the ageing temperature $\left(130^{\circ} \mathrm{C}\right.$ and $\left.140^{\circ} \mathrm{C}\right)$ led to a decrease in the hardness value.

- The maximum tensile strength was obtained for the alloy aged at $120^{\circ} \mathrm{C}$. Further increase in the ageing temperature $\left(130{ }^{\circ} \mathrm{C}\right.$ and $\left.140{ }^{\circ} \mathrm{C}\right)$ led to a decrease in the tensile strength.

\section{References}

[1] A.K. Jha, K. Sreekumar, J Fail. Anal. Preven. 8, $327(2008)$.

[2] A. Heinz, A. Haszler, C. Keidel, S. Moldenhauer, R. Benedictus, W.S. Miller, Mater. Sci. Eng. A 280, $102(2000)$.

[3] K.H. Rendigs, Mater. Sci. Forum 242, 11 (1997).

[4] D. Özyürek, R. Yilmaz, E. Kibar, J. Fac. Eng. Archit. 7, 193 (2012).

[5] R. Clark, B. Coughran, I. Traina, A. Hernandez, T. Scheck, C. Etuk, J. Peters, E.W. Lee, J. Ogren, O.S. Es-Said, Eng. Failure Anal. 12, 520 (2005).

[6] M. Song, K. Chen, J. Mater. Sci. 43, 5265 (2008).

[7] J.F. Li, Z.W. Peng, C.X. Li, Z.G. Jia, W.J. Chen, Z.Q. Zheng, Trans. Nonferrous Met. Soc. China 18, 755 (2008).

[8] P.V. Kumar, G.M. Reddy, K.S. Rao, Def. Technol. 11, $362(2015)$.

[9] A. Abolhasani, A. Zarei-Hanzaki, H.R. Abedi, M.R. Rokni, Mater. Des. 34, 631 (2012).

[10] N. Kamp, I. Sinclair, M.J. Starink, Metall. Mater. Trans. A 33, 1125 (2002).

[11] A. Fakioglu, D. Özyürek, R. Yilmaz, High Temp. Mater. Process. 32, 345 (2013).

[12] A. Kalyon, D. Özyürek, Acta Phys. Pol. A 131, 150 (2017).

[13] A.K. Mukhopadhyay, Q.B. Yang, S.R. Singh, Acta Metall. Mater. 42, 3083 (1994). 